\title{
PRELIMINARY DIGITAL GEOLOGIC MAPS OF THE MARIPOSA, KINGMAN, TRONA, AND DEATH VALLEY SHEETS, CALIFORNIA
}

U.S. GEOLOGICAL SURVEY

Open-File Report 94-318

Prepared in cooperation with the NEVADA OPERATIONS OFFICE U.S. DEPARTMENT OF ENERGY under Interagency Agreement DE-AI08-92NV10874

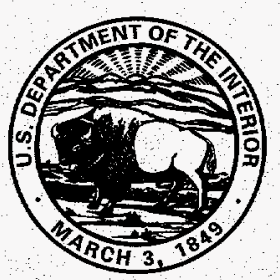




\section{Preliminary Digital Geologic Maps of the Mariposa, Kingman, Trona, and Death Valley Sheets, California}

by Frank A. D'Agnese, Claudia C. Faunt, and A. Keith Turner

\section{U.S. GEOLOGICAL SURVEY}

Open-File Report 94-318

Prepared in cooperation with the

NEVADA OPERATIONS OFFICE

U.S. DEPARTMENT OF ENERGY under

Interagency Agreement DE-Al08-92NV10874

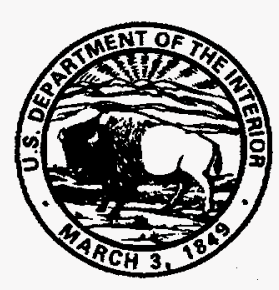




\section{U.S. DEPARTMENT OF THE INTERIOR BRUCE BABBITT, Secretary}

U.S. GEOLOGICAL SURVEY

Gordon P. Eaton, Director

The use of trade, product, industry, or firm names is for descriptive purposes only and does not imply endorsement by the U.S. Government.

For additional information write to:

Chief, Earth Science Investigations Program

Yucca Mountain Project Branch

U.S. Geological Survey

Box 25046, MS 421

Denver Federal Center

Denver, CO 80225
Copies of this report can be purchased from:

U.S. Geological Survey

Earth Science Information Center

Open-File Reports Section

Box 25286, MS 517

Denver Federal Center

Denver, CO 80225 


\section{DISCLAIMER}

Portions of this document may be illegible in electronic image products. Images are produced from the best available original document. 


\section{CONTENTS}

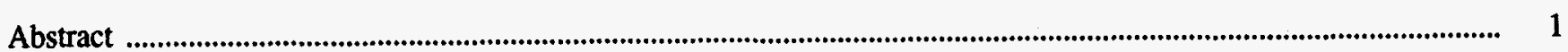

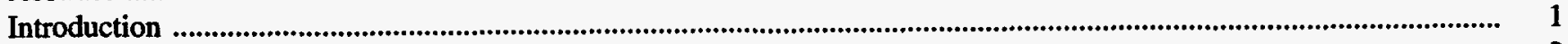

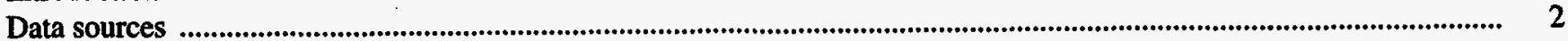

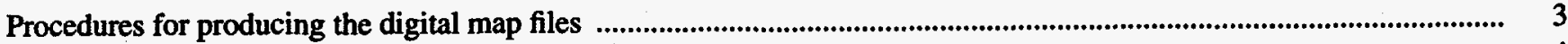

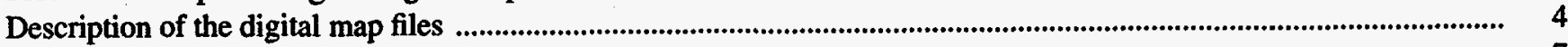

Conclusions

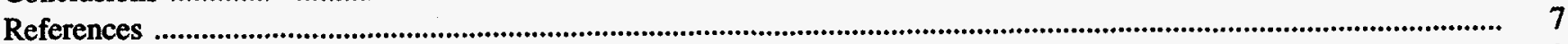

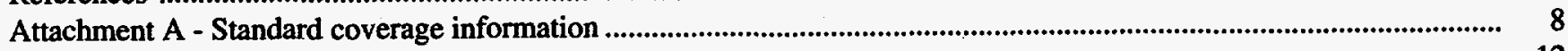

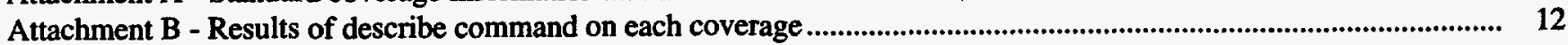

\section{FIGURES}

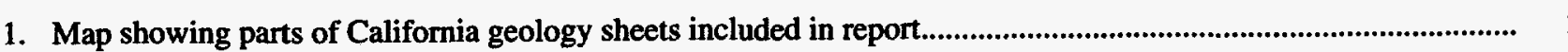

\section{TABLES}

1. Geologic unit ID codes for ARC/NFO geologic coverages

\section{Keywords:}

digital map, Death Valley, Yucca Mountain

\section{DISCLAIMER}

This report was prepared as an account of work sponsored by an agency of the United States Government. Neither the United States Government nor any agency thereof, nor any of their employees, makes any warranty, express or implied, or assumes any legal liability or responsibility for the accuracy, completeness, or usefulness of any information, apparatus, product, or process disclosed, or represents that its use would not infringe privately owned rights. Reference herein to any specific commercial product, process, or service by trade name, trademark, manufacturer, or otherwise does not necessarily constitute or imply its endorsement, recommendation, or favoring by the United States Government or any agency thereof. The views and opinions of authors expressed herein do not necessarily state or reflect those of the United States Government or any agency thereof. 


\title{
Preliminary Digital Geologic Maps of the Mariposa, Kingman, Trona, and Death Valley Sheets, California
}

\author{
By Frank A. D'Agnese, Claudia C. Faunt, and A. Keith Turner
}

\section{Abstract}

Parts of four 1:250,000-scale geologic maps by the California Department of Natural Resources, Division of Mines and Geology have been digitized for use in hydrogeologic characterization. These maps include the area of California between lat $35^{\circ} \mathrm{N}$; long $115^{\circ} \mathrm{W}$. and lat $38^{\circ} \mathrm{N}$., long $118^{\circ} \mathrm{W}$. of the Kingman Sheet (Jennings, 1961), Trona Sheet (Jennings and others, 1962), Mariposa Sheet (Strand, 1967), and Death Valley Sheet (Streitz and Stinson, 1974). These digital maps are being released by the U.S. Geological Survey in the ARC/INFO Version 6.1 Export format. The digitized data include geologic unit boundaries, fault traces, and identity of geologic units.

The procedure outlined in U.S. Geological Survey Circular 1054 (Soller and others, 1990) was used during the map construction. The procedure involves transferring hard-copy data into digital format by scanning manuscript maps, manipulating the digital map data, and outputting the data. Most of the work was done using Environmental Systems Research Institute's ARC/INFO software. The digital maps are available in ARC/INFO Rev 6.1 Export format, from the USGS, Yucca Mountain Project, in Denver, Colorado.

\section{INTRODUCTION}

Yucca Mountain on the Nevada Test Site in southwestern Nevada is being studied as a potential site for a high-level nuclear waste repository. The U.S. Geological Survey (USGS) is evaluating the hydrology of the site as part of the U.S. Department of Energy Yucca Mountain Site Characterization Project. Because of the potential for radionuclides to be transported by ground water from the repository to the accessible environment, the regional hydrologic regime at Yucca Mountain is being studied.
As part of this study, regional geologic maps of the Death Valley region have been digitized for use in a geographic information system (GIS). The area covered by this report is a triangular section of southeastern California bounded by the Nevada-California border on the northeast, by long $118^{\circ} \mathrm{W}$. on the west, and by lat $35^{\circ} \mathrm{N}$. on the south (fig. 1).

Parts of four 1:250,000-scale geologic maps, included in the Geologic Atlas of California, which was produced by the California Department of Natural Resources, Division of Mines and Geology (Bacon, 1971), cover this region. These map sheets are: $r$

1. Death Valley Sheet (Streitz and Stinson, 1974),

2. Kingman Sheet (Jennings, 1961),

3. Mariposa Sheet (Strand, 1967), and

4. Trona Sheet (Jennings and others, 1962).

Although the various map sheets in the Geologic Atlas of California generally correspond to the standard 1:250,000-scale topographic map quadrangles and take their names from these quadrangles, the sheets were extended to encompass small parts of adjacent quadrangles, in some cases where they border adjacent States. In this way, only 27 geologic map sheets were required to produce the Geologic Atlas of California. One such extension occurs within this data release. The Mariposa Geologic Sheet was extended eastward from the Mariposa topographic map quadrangle to include a small triangular portion of California on the Goldfield, Nevada, topographic map quadrangle. In fact, the digital geologic data reported here for the Mariposa Sheet fall entirely within the geographic extent of the Goldfield topographic map quadrangle.

Digital maps are commonly used for applications other than those for which they were originally intended. Misuse of digital data, a problem not unique to digital map files, arises when these data are used in ways that go beyond their intended purpose. This documentation is intended to allow others to judge the appropriateness of these digital geologic map files for their uses and to allow trained persons with similar hardware and software to reconstruct these maps from the digital files. To use the information in this report, 


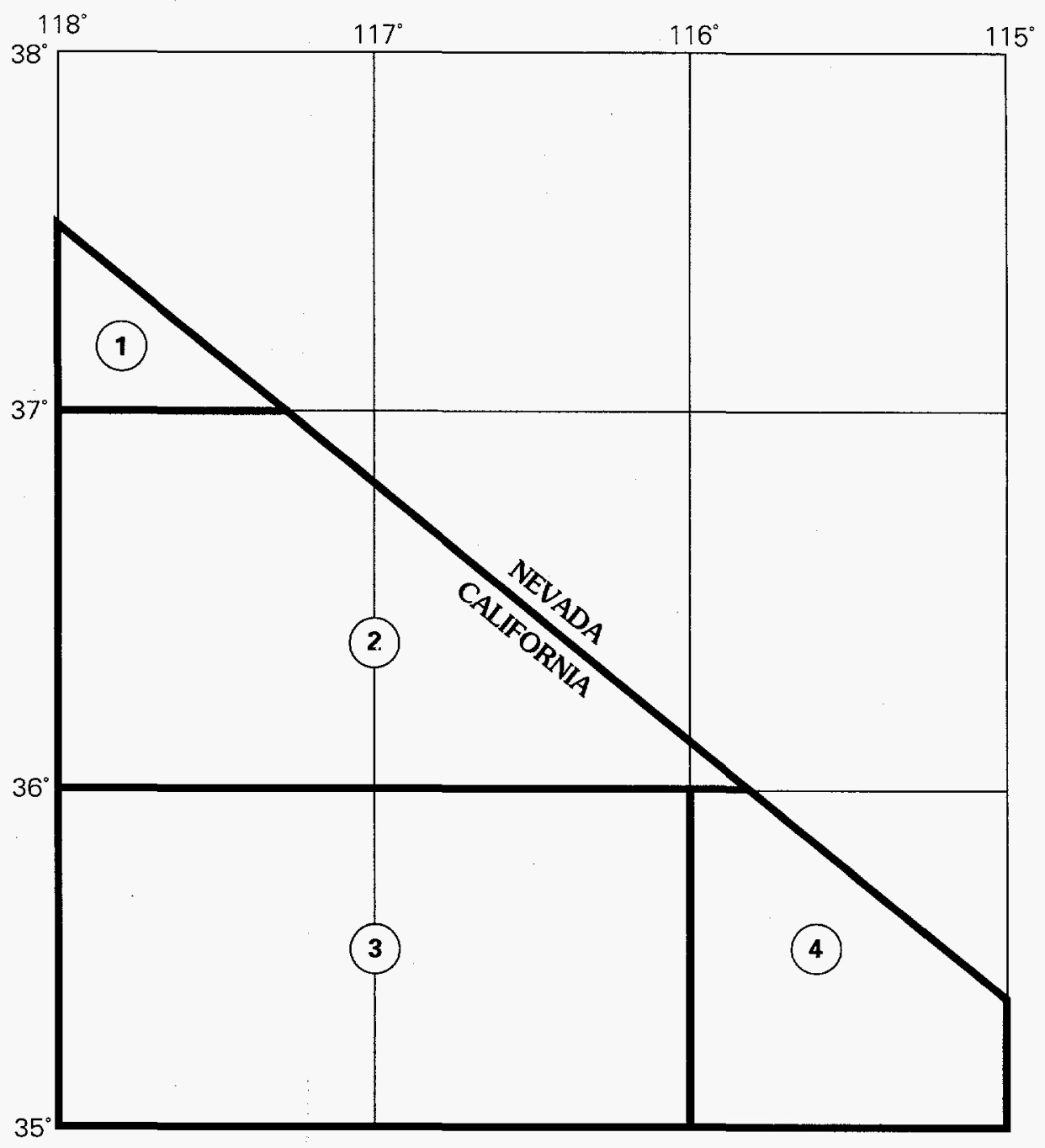

(1) Mariposa Sheet (Strand, 1967)

(2) Death Valley Sheet (Streitz and Stinson, 1974)

(3) Trona Sheet (Jennings and others, 1962)

(4) Kingman Sheet (Jennings, 1961)

Figure 1. Map showing parts of California geology sheets included in report.

one needs knowledge of general map and cartographic concepts, the PRIMOS and/or UNIX operating systems, ARC/INFO, file-management concepts, and data-archiving systems.

The digital maps are available in ARC/INFO Rev 6.1 Export format, from the USGS, Denver, online repository on Internet (via 'anonymous ftp') at ympbserv1.cr.usgs.gov.

\section{DATA SOURCES}

For the Death Valley, Trona, and Kingman Sheets, two black-and-white copies plotted on scale- stable acetate base materials, one showing the geologic unit boundaries and the other the faults (each containing geographic control points), were obtained from the California Division of Mines and Geology. These copies show the geologic boundaries and faults exactly as they are shown on the original published maps of the Geologic Atlas of California (Bacon, 1971). Such materials were not available for the Mariposa Sheet; thus, for the small part of this sheet that was required for this work, the geologic boundaries and the faults were traced from a library copy of the published paper map sheet onto two separate scale-stable masters, along with appropriate control points. 
After appropriate digitization and verification procedures described in the following section, the digital data files include polygon boundaries, fault traces, and identification of geologic units. These data files are distributed in ARC/INFO Rev. 6.1 Export format.

\section{PROCEDURES FOR PRODUCING THE DIGITAL MAP FILES}

A procedure for transferring map documents to digital file format is described in Soller and others (1990). This procedure formed the basis for all data digitization described herein. The fault maps were scanned by using a raster-to-vector Tektronix scanner installed in the USGS GIS Laboratory in Denver. The geological boundary maps were scanned commercially and supplied as ARC/INFO vector files. The USGS performed all further processing on the entire suite of vector files. This processing was similar to that described by Bawiec and others (1992) during their development of the digital version of the geologic map of Nevada (Turner and Bawiec, 1991). The processing removed artifacts of the scanning process, transformed the files into a suitable geographic coordinate system, and edited the files to achieve accurate topology. The procedure can be summarized as follows:

1. Geologic unit contacts, faults, and control points were obtained from black-and-white copy. The map units used in the Geologic Atlas of California describe rocks of differing ages and lithology. Therefore, geologic unit contacts represent major changes in rock type and age. In some cases, volcanic units occurring on some map sheets are distinguished by mineralogy, texture, or mode of origin. These distinctions are not always included in the digital reproduction because such descriptions were not necessary for regional hydrogeologic characterization.

2. The black-and-white copies of geologic contacts were converted to digital format by a commercial subcontractor using raster scanners. The black-and-white copies of the faults were converted to digital format using a Tektronix raster scanner at the USGS GIS Laboratory in Denver, Colorado. The digital files were then converted into a sequence of individual ARC/INFO coverages.

3. The resulting digital map coverages were manually reviewed and corrected for scanning errors such as gaps in lines, stray lines, and incorrect line intersections. The control points were converted to geographic registration points (ARC/INFO tics). The map coverages were then geographically registered into Zone 11 of the Universal Transverse Mercator coordinate system.

4. For the geologic units coverages, the digital boundaries, represented by lines (or "arcs" in ARC/INFO terminology), were further analyzed to represent polygonal information defining the extent of each geologic map unit. ARC/ INFO uses rules of planar enforcement to construct a topologically correct sequence of polygons from such boundary lines. This requires a point to be placed within each polygon representing a geologic unit area, and these points to be identified or labeled with an alphanumeric code representing that geologic unit. Using ARC/INFO commands, the coverages were analyzed (by the ARC/INFO "clean" and "build" commands) until no errors in topology were identified. For the fault coverages, construction of polygon topology was not required. The faults were edited as line string entities.

5. Tables containing appropriate attributes were constructed within the ARC/INFO system. The digital files first were processed on a PRIME computer system using ARC/INFO Version 5.0.1. Later, the files were moved to a SunSparc Workstation and translated to ARC/INFO Version 6.0, then to Version 6.1.

6. Each of the coverages were plotted, using ARCPLOT, at the original map scale $(1: 250,000)$ on a Calcomp Electrostatic Plotter. The maps were then overlaid on the manuscript sheets and checked for discrepancies. Errors less than 1 kilometer on the ground were not corrected. To ensure that the geologic unit and fault coverages were geographically consistent, the geologic unit contact coverages were digitally overlaid onto the fault coverage. Where discrepancies existed that were larger than $250 \mathrm{~m}$, arcs were adjusted to agree with the fault coverage. Then, each of the digital geologic map units were plotted in appropriate colors and agreement with the published maps was checked. Attribution errors were cor- 
rected. The specifications for snap distances, tolerances, and other attributes can be found in Attachments A and B.

7. The individual map coverages were then converted to ASCII format using the "export cover" function of ARC/INFO. These ARC EXPORT files were then written to an archiving medium.

A number of limitations are inherent in the creation of these digital map files. They include:

1. The maps are only, at best, accurate to the scale of the original digitized map, in this case $1: 250,000$. However, since the final map product was compiled at a scale of $1: 500,000$, some errors translating to less than $1 \mathrm{~km}$ on the ground were not corrected.

2. The borders of the original California Geologic Atlas map sheets do not match exactly. This is especially true of the Death Valley Sheet, which was remapped and reissued later than the other sheets. These digital map files retain the differences inherent on the original map sources.

Certain criteria were used to decide which material to include and exclude. Only the geologic boundaries, unit identification, and fault data were included in the digitization procedure. Symbols such as anticlines, synclines, strikes, and dips were not included. Dashed contacts and faults were treated as solid lines and were not separated in the data base.

Inevitably, judgments were made by the authors in creating these digital map files. Units that were unlabeled on the source map were lumped with nearby units. Whenever possible, this was done after consulting a larger scale, more detailed, geologic map of the area.

Some of the source materials have some minor errors or discrepancies. As previously noted, the geologic units and faults have some abrupt changes on the map borders (especially between the Death Valley map and adjacent maps). No attempt was made to correct this problem.

\section{DESCRIPTION OF THE DIGITAL MAP FILES}

\section{File Names:}

The digital map files cover the triangular section of southeastern California between lat $35^{\circ}$ and $38^{\circ} \mathrm{N}$. and long $115^{\circ}$ and $118^{\circ} \mathrm{W}$. (fig. 1). The digital map files were developed as coverages within ARC/INFO Version 6.1 and are distributed in ARC/INFO's ASCII uncompressed Export format. There are four individual map sheets, and for each there are separate coverages for the faults and geologic units. The resulting eight files have the following names:

\begin{tabular}{|c|c|c|}
\hline Geology & Faults & Sheet name \\
\hline Deathvalgeo.e00 & Deathvalf.e00 & $\begin{array}{l}\text { Death Valley } \\
\text { (Streitz and } \\
\text { Stinson, } \\
\text { (1974) }\end{array}$ \\
\hline Kingmangeo.e00 & Kingmanf.e00 & $\begin{array}{l}\text { Kingman } \\
\text { (Jennings, } \\
\text { 1961) }\end{array}$ \\
\hline Mariposageo.e 00 & Mariposaf.e00 & $\begin{array}{l}\text { Mariposa } \\
\text { (Strand, } \\
(1967)\end{array}$ \\
\hline Tronageo.e00 & Tronaf.e00 & $\begin{array}{l}\text { Trona } \\
\text { (Jennings and } \\
\text { others, 1962) }\end{array}$ \\
\hline
\end{tabular}

\section{Data Elements:}

The geologic unit polygons on these digital map files are attributed to correspond to the geologic units used by the Geologic Atlas of California. One hundred and twenty-four geologic units were used to represent the statewide geology of California (Bacon, 1971). Each map sheet has the same margin legend and is accompanied by its own explanatory data sheet, which includes bibliographic references and a table of stratigraphic nomenclature defining the correspondence between the map units and the individual formations. The fault traces on the fault coverages are not attributed.

Within the region of interest, the geologic materials range in age from Precambrian to Holocene and are composed of metamorphic rocks, carbonate and clastic sedimentary rocks of both marine and continental origin, and plutonic and volcanic igneous rocks. This diverse geology is described by 74 geologic units (out of the 124 California statewide units), as listed in table 1. The formation codes shown in table 1 are those described in the Geologic Atlas of 
Table 1. Geologic Unit ID codes for ARC/INFO geologic coverages

\begin{tabular}{|c|c|c|c|c|}
\hline Formation & Kingman & Mariposa & Trona & Death Valley \\
\hline \multicolumn{5}{|c|}{ Sedimentary } \\
\hline Qs & 1026 & 2006 & 3013 & 4007 \\
\hline Qal & 1004 & 2002 & 3005 & 4004 \\
\hline Qst & None & None & 3038 & 4019 \\
\hline Q1 & 1012 & 2014 & 3002 & 4003 \\
\hline Qc & 1008 & 2001 & 3001 & 4011 \\
\hline QP & None & 2003 & 3032 & 4027 \\
\hline $\mathrm{Pc}$ & None & 2018 & 3017 & 4018 \\
\hline Pmlc & None & None & 3019 & None \\
\hline $\mathrm{Mc}$ & None & None & 3046 & None \\
\hline Muc & None & None & 3027 & None \\
\hline Mmc & None & None & 3061 & None \\
\hline $0 c$ & None & 2026 & 3050 & 4035 \\
\hline Epc & None & None & 3020 & None \\
\hline $\mathrm{Tc}$ & 1002 & 2017 & 3011 & 4013 \\
\hline $\mathrm{Jml}$ & 1027 & None & None & None \\
\hline $\mathbf{R}$ & None & None & 3007 & 4037 \\
\hline $\mathbf{m}$ & None & None & 3037 & None \\
\hline m (ls) & None & None & None & 4022 \\
\hline ms & None & None & 3057 & None \\
\hline $\mathbb{P}$ & 1011 & 2019 & 3021 & 4020 \\
\hline $\mathbf{R}$ & 1029 & None & 3042 & 4009 \\
\hline C & 1010 & 2015 & 3063 & None \\
\hline $\mathrm{CP}$ & 1019 & 2007 & None & 4028 \\
\hline $\mathbf{C M}$ & 1020 & 2008 & 3049 & 4031 \\
\hline D & 1021 & 2016 & None & 4006 \\
\hline$S$ & None & 2010 & None & 4030 \\
\hline 0 & None & 2009 & None & 4002 \\
\hline$\epsilon$ & 1001 & 2005 & 3009 & 4023 \\
\hline$€ ?$ & 1023 & 2028 & 3066 & 4012 \\
\hline pe & None & None & None & 4083 \\
\hline$p \in g$ & 1013 & None & 3028 & None \\
\hline pes & None & None & 3068 & 4998 \\
\hline lpe & 1030 & 2031 & 3008 & 4029 \\
\hline ep€ & 1000 & $\begin{array}{l}\text { None } \\
\text { Igneous }\end{array}$ & 3040 & 4040 \\
\hline Qrv ${ }^{b}$ & 1007 & None & None & None \\
\hline QrvP & 1022 & 2024 & None & 4034 \\
\hline$Q p v^{a}$ & None & None & 3035 & None \\
\hline Qpv $v^{b}$ & 1003 & 2030 & 3018 & 4014 \\
\hline Qpvp & None & 2025 & None & 4015 \\
\hline$Q p v^{r}$ & None & None & 3033 & 4103 \\
\hline Pv & None & None & 3047 & None \\
\hline $\mathrm{Pv}^{\mathrm{a}}$ & None & None & 3023 & 4041 \\
\hline
\end{tabular}


Table 1. Geologic Unit ID codes for ARC/NFO geologic coverages --Continued

\begin{tabular}{|c|c|c|c|c|}
\hline Formation & Kingman & Mariposa & Trona & Death Valley \\
\hline \multicolumn{5}{|c|}{ Igneous-Continued } \\
\hline $\mathbf{P v} \mathbf{v}^{\mathrm{b}}$ & None & 2011 & 3045 & 4000 \\
\hline Pvp & None & 2029 & 3022 & 4008 \\
\hline $\mathrm{Pv}^{\mathrm{r}}$ & None & None & 3060 & 4024 \\
\hline Mv & None & None & 3048 & None \\
\hline $\mathbf{M v}^{\mathbf{a}}$ & None & None & 3051 & None \\
\hline $\mathbf{M} \mathbf{v}^{\mathbf{b}}$ & None & None & 3054 & None \\
\hline $\mathbf{M v} \mathbf{v}^{\mathrm{P}}$ & None & None & 3026 & None \\
\hline$M v^{r}$ & 1018 & None & 3030 & None \\
\hline Ov & None & None & 3014 & None \\
\hline QTV & None & None & 3039 & None \\
\hline $\mathrm{QTV}^{\mathrm{a}}$ & None & None & 3003 & None \\
\hline $\mathrm{QT}^{\mathrm{b}}$ & None & None & 3034 & None \\
\hline $\mathrm{Tgr}$ & None & None & None & 4025 \\
\hline $\mathrm{Ti}$ & None & None & 3029 & 4112 \\
\hline $\mathbf{T i}^{\mathbf{a}}$ & None & None & 3041 & None \\
\hline $\mathbf{T i}^{\mathbf{b}}$ & None & None & 3069 & 4032 \\
\hline $\mathrm{Ti}^{\mathbf{r}}$ & None & 2022 & 3055 & 4016 \\
\hline $\operatorname{Tv}$ & 1005 & None & 3006 & 4010 \\
\hline$T v^{a}$ & 1016 & None & 3004 & 4042 \\
\hline$T v^{b}$ & 1015 & None & 3036 & 4038 \\
\hline$T v^{p}$ & 1017 & 2013 & 3031 & 4026 \\
\hline$T v^{r}$ & 1018 & 2012 & 3044 & 4005 \\
\hline gr & 1006 & 2004 & 3010 & 4001 \\
\hline bi & None & None & 3012 & 4039 \\
\hline JR & 1024 & None & 3025 & 4036 \\
\hline mv & None & 2027 & 3052 & 4043 \\
\hline gr-m & 1025 & None & 3024 & None \\
\hline $\mathrm{PPv}$ & None & None & 3058 & None \\
\hline pegr & 1014 & $\begin{array}{l}\text { None } \\
\text { Other }\end{array}$ & None & None \\
\hline Water & None & None & None & 4021 \\
\hline Landslide & None & None & None & 4033 \\
\hline
\end{tabular}


California map sheets and their accompanying explanatory data sheets, which should be referred to for more information.

Not all geologic units occur on each map sheet; the word "None" in table 1 is used to show where a particular geologic unit is absent on a map sheet. Each geologic unit was given a unique numeric ID code on each map sheet. The codes were defined in the 1000-series for the Kingman Sheet, in the 2000-series for the Mariposa Sheet, in the 3000-series for the Trona Sheet, and in the 4000-series for the Death Valley Sheet. Table 1 summarizes the valid geologic unit ID codes for each sheet. These codes are stored as "user-id" in the appropriate ARC/INFO attribute tables (*.PAT files).

\section{Map Projection:}

The maps are in the Universal Transverse Mercator coordinate system, Zone 11, using the Clarke 1866 Spheroid. Coordinates are in meters, with no $\mathrm{x}$ - or $\mathrm{y}$ - offsets.

\section{Copyright and Distribution Restrictions:}

These data are in the public domain and contain no copyright or distribution restrictions.

\section{CONCLUSIONS}

These digital map files appear to meet their intended application of being used as part of a smaller scale regional hydrogeologic map. Additional work may be necessary before the maps can be used for other purposes. Joining of the maps is an obvious next step to the process. Digitization errors and actual errors or changes of interpretations between maps will cause problems during this procedure. The authors have attempted this procedure after the existing geologic units were combined, or "lumped," into fewer more general units.

\section{REFERENCES}

Bacon, Forrest, 1971, California's geologic atlas complete: California Geology, v. 24, no. 6, California Division of Mines and Geology, p. 99-103. (MOL.19941018.0002)

Bawiec, W.J., Traudt, D.K., Ambroziak, R.A., Arndt, R.E., 1992, The evolution of a digital geologic coveragefrom paper to CD-ROM: U.S. Geologic Survey Bulletin 2016, chap. E, p. E1-E8. (MOL.19941102.0002)

Jennings, C.W., 1961, Geologic Map of California-Kingman Sheet: California Division of Mines and Geology, Sacramento, California, scale 1:250,000. (MOL.19941122.0002)

Jennings, C.W., Burnett, J.L., and Troxel, B.W., 1962, Geologic map of California-Trona Sheet: California Division of Mines and Geology, Sacramento, California, scale 1:250,000. (MOL.19941122.0003)

Soller, D.R., Stettner, W.R., Lanfear, K.J., and Aitken, D.S., 1990 , A user's manual for a method of map scanning and digital editing for thematic map production and data-base construction: U.S. Geological Survey Circular 1054, 38 p. (MOL.19941102.0006)

Strand, R.G., 1967, Geologic map of California-Mariposa Sheet: California Division of Mines and Geology, Sacramento, California, scale 1:250,000. (MOL.19941122.0004)

Streitz, Robert, and Stinson, M.C., 1974, Geologic map of California-Death Valley Sheet: California Division of Mines and Geology, Sacramento, California, scale 1:250,000. (NNA.901204.0005)

Turner, R.M., and Bawiec, W.J., 1991, Digital geologic coverage of Nevada - a digital representation of the 1978 geologic map of Nevada: U.S. Geologic Survey Digital Data Series 2. (MOL.19941129.0075)

NOTE: Parenthesized numbers following each cited reference are for U.S. Department of Energy OCRWM Records Management purposes only and should not be used when ordering the publication. 


\section{ATTACHMENT A}

\section{Standard Coverage Information}

Dataset name:

Dataset format:

Dataset description:

Dataset geographic extent:

Source name:

Source format:

Source description:

Source author:

Source geographic extent:

Year source was compiled/published:

Scale of source:

Source purchased from:

Digitized by:

Digitized using:

Projection characteristics of source:

Projection characteristics of final dataset:
Deathvalgeo.E00

ARC Export Coverage

Geologic Units of Death Valley Sheet

California portio of lat $36^{\circ}-37^{\circ} \mathrm{N}$ and long $116^{\circ}-118^{\circ} \mathrm{W}$

Death Valley Sheet

Acetate stable map sheet

Geologic Map of Death Valley Sheet

California Division of Mines and Geology, Streitz and Stinson

California portion of lat $36^{\circ}-37^{\circ} \mathrm{N}$ and long $116^{\circ}-118^{\circ} \mathrm{W}$

1974

$1: 250,000$

California Division of Mines and Geology

U.S. Geological Survey and contractors

Raster scanner, line-following scanner

Universal Transverse Mercator

Universal Transverse Mercator

\section{Standard Coverage Information}

Dataset name:

Dataset format:

Dataset description:

Dataset geographic extent:

Source name:

Source format:

Source description:

Source author:

Source geographic extent:

Year source was compiled/published:

Scale of source:

Source purchased from:

Digitized by:

Digitized using:

Projection characteristics of source:

Projection characteristics of final dataset:
Deathvalf.E00

ARC Export Coverage

Fault Traces of Death Valley Sheet

California portion of lat $36^{\circ}-37^{\circ} \mathrm{N}$ and long $116^{\circ}-118^{\circ} \mathrm{W}$

Death Valley Sheet

Acetate stable map sheet

Geologic Map of Death Valley Sheet

California Division of Mines and Geology, Streitz and Stinson

California portion of lat $36^{\circ}-37^{\circ} \mathrm{N}$ and long $116^{\circ}-118^{\circ} \mathrm{W}$

1974

$1: 250,000$

California Division of Mines and Geology

U.S. Geological Survey and contractors

Tektronix raster scanner

Universal Transverse Mercator

Universal Transverse Mercator 


\section{Standard Coverage Information}

Dataset name:

Dataset format:

Dataset description:

Dataset geographic extent:

Source name:

Source format:

Source description:

Source author:

Source geographic extent:

Year source was compiled/published:

Scale of source:

Source purchased from:

Digitized by:

Digitized using:

Projection characteristics of source:

Projection characteristics of final dataset:
Kingmangeo.E00

ARC Export Coverage

Geologic Units of Kingman Sheet

California portion of lat $35^{\circ}-36^{\circ} \mathrm{N}$ and long $115^{\circ}-116^{\circ} \mathrm{W}$

Kingman Sheet

Acetate stable map sheet

Geologic Map of Kingman Sheet

California Division of Mines and Geology, Jennings

California portion of lat $35^{\circ}-36^{\circ} \mathrm{N}$ and long $115^{\circ}-116^{\circ} \mathrm{W}$ 1961

$1: 250,000$

California Division of Mines and Geology

U.S. Geological Survey and contractors

Raster scanner, line-following scanner

Universal Transverse Mercator

Universal Transverse Mercator

\section{Standard Coverage Information}

Dataset name:

Dataset format:

Dataset description:

Dataset geographic extent:

Source name:

Source format:

Source description:

Source author:

Source geographic extent:

Year source was compiled/published:

Scale of source:

Source purchased from:

Digitized by:

Digitized using:

Projection characteristics of source:

Projection characteristics of final dataset:
Kingmanf.E00

ARC Export Coverage

Fault Traces of Kingman Sheet

California portion of lat $35^{\circ}-36^{\circ} \mathrm{N}$ and long $115^{\circ}-116^{\circ} \mathrm{W}$

Kingman Sheet

Acetate stable map sheet

Geologic Map of Kingman Sheet

California Division of Mines and Geology, Jennings

California portion of lat $35^{\circ}-36^{\circ} \mathrm{N}$ and long $115^{\circ}-116^{\circ} \mathrm{W}$

1961

$1: 250,000$

California Division of Mines and Geology

U.S. Geological Survey and contractors

Tektronix raster scanner

Universal Transverse Mercator

Universal Transverse Mercator 


\section{Standard Coverage Information}

Dataset name:

Dataset format:

Dataset description:

Dataset geographic extent:

Source name:

Source format:

Source description:

Source author:

Source geographic extent:

Year source was compiled/published:

Scale of source:

Source purchased from:

Digitized by:

Digitized using:

Projection characteristics of source:

Projection characteristics of final dataset:
Mariposageo.E00

ARC Export Coverage

Geologic Units of Mariposa Sheet

California portion of lat $37^{\circ}-38^{\circ} \mathrm{N}$ and long $117^{\circ}-118^{\circ} \mathrm{W}$

Mariposa Sheet

Mylar trace of map sheet

Geologic Map of Mariposa Sheet

California Division of Mines and Geology, Strand

California portion of lat $37^{\circ}-38^{\circ} \mathrm{N}$ and long $117^{\circ}-118^{\circ} \mathrm{W}$

1967

1:250,000

California Division of Mines and Geology

U.S. Geological Survey and contractors

Tektronix raster scanner

Universal Transverse Mercator

Universal Transverse Mercator

\section{Standard Coverage Information}

Dataset name:

Dataset format:

Dataset description:

Dataset geographic extent:

Source name:

Source format:

Source description:

Source author:

Source geographic extent:

Year source was compiled/published:

Scale of source:

Source purchased from:

Digitized by:

Digitized using:

Projection characteristics of source:

Projection characteristics of final dataset:
Mariposaf.E00

ARC Export Coverage

Fault Traces of Mariposa Sheet

California portion of lat $37^{\circ}-38^{\circ} \mathrm{N}$ and long $117^{\circ}-118^{\circ} \mathrm{W}$

Mariposa Sheet

Mylar trace of map sheet

Geologic Map of Mariposa Sheet

California Division of Mines and Geology, Strand

California portion of lat $37^{\circ}-38^{\circ} \mathrm{N}$ and long $117^{\circ}-118^{\circ} \mathrm{W}$ 1967

1:250,000

California Division of Mines and Geology

U.S. Geological Survey and contractors

Tektronix raster scanner

Universal Transverse Mercator

Universal Transverse Mercator 


\section{Standard Coverage Information}

Dataset name:

Dataset format:

Dataset description:

Dataset geographic extent:

Source name:

Source format:

Source description:

Source author:

Source geographic extent:

Year source was compiled/published:

Scale of source:

Source purchased from:

Digitized by:

Digitized using:

Projection characteristics of source:

Projection characteristics of final dataset:
Tronageo.E00

ARC Export Coverage

Geologic Units of Trona Sheet

California portion of lat $35^{\circ}-36^{\circ} \mathrm{N}$ and long $116^{\circ}-118^{\circ} \mathrm{W}$

Trona Sheet

Acetate stable map sheet

Geologic Map of Trona Sheet

California Division of Mines and Geology, Jennings and others California portion of lat $35^{\circ}-36^{\circ} \mathrm{N}$ and long $116^{\circ}-118^{\circ} \mathrm{W}$ 1962

$1: 250,000$

California Division of Mines and Geology

U.S. Geological Survey and contractors

Raster scanner, line-following scanner

Universal Transverse Mercator

Universal Transverse Mercator

\section{Standard Coverage Information}

Dataset name:

Dataset format:

Dataset description:

Dataset geographic extent:

Source name:

Source format:

Source description:

Source author:

Source geographic extent:

Year source was compiled/published:

Scale of source:

Source purchased from:

Digitized by:

Digitized using:

Projection characteristics of source:

Projection characteristics of final dataset:
Tronaf.E00

ARC Export Coverage

Fault Traces of Trona Sheet

California portion of lat $35^{\circ}-36^{\circ} \mathrm{N}$ and long $116^{\circ}-118^{\circ} \mathrm{W}$

Trona Sheet

Acetate stable map sheet

Geologic Map of Trona Sheet

California Division of Mines and Geology, Jennings and others

California portion of lat $35^{\circ}-36^{\circ} \mathrm{N}$ and long $116^{\circ}-118^{\circ} \mathrm{W}$

1962

$1: 250,000$

California Division of Mines and Geology

U.S. Geological Survey and contractors

Tektronix raster scanner

Universal Transverse Mercator

Universal Transverse Mercator 


\section{ATTACHMENT B}

\section{Results of Describe Command on Each Coverage}

Description of SINGLE precision coverage deathvalgeo

ARCS

$\begin{array}{lcc}\text { Arcs } & = & 8907 \\ \text { Segments } & = & 129054 \\ 0 \text { bytes of Arc Attribute Data }\end{array}$

NODES

Nodes $=6454$

0 bytes of Node Attribute Data

Subclass

(blank):

TOLERANCES

$\begin{array}{ll}\text { Fuzzy } & =79.202 \mathrm{~V} \\ \text { Dangle } & =121.849 \mathrm{~V}\end{array}$

\section{ANNOTATIONS}

Annotations

0
POLYGONS

Polygons $=3091$

Polygon Topology is present.

20 bytes of Polygon Attribute Data

\section{POINTS}

Label Points $=3090$

Text Attribute Data

0 bytes

\section{COVERAGE BOUNDARY}

$$
\begin{array}{ll}
X \min & =409851.594 \\
X \max & =599775.000
\end{array}
$$$$
\text { Ymin }=3983738.000
$$

Ymax

$=4095113.500$

\section{STATUS}

The coverage has not been Edited since the last BUILD or CLEAN. 
ARCS

Arcs $=6201$

Segments $=27383$

28 bytes of Arc Attribute Data

NODES

Nodes $=7723$

0 bytes of Node Attribute Data

TOLERANCES

$\begin{array}{ll}\text { Fuzzy } & =0.839 \mathrm{~V} \\ \text { Dangle } & =0.000 \mathrm{~V}\end{array}$
POLYGONS

Polygons $=0$

There is NO Polygon Topology.

0 bytes of Polygon Attribute Data

POINTS

Label Points $=0$

SECONDARY FEATURES

Tics $=631$

Links $\quad=0$

COVERAGE BOUNDARY

$\begin{array}{llll}X \min & =410034.875 & Y \min & =3983716.000 \\ X \max & =588902.000 & Y \max & =4095021.000\end{array}$

\section{STATUS}

The coverage has not been Edited since the last BUILD or CLEAN.

NO COORDINATE SYSTEM DEFINED 


\section{ARCS}

Arcs $=\quad 1418$
Segments $=\quad 39384$
0 bytes of Arc Attribute Data

NODES

Nodes $=1021$

0 bytes of Node Attribute Data

\section{POLYGONS}

Polygons $=576$

Polygon Topology is present.

24 bytes of Polygon Attribute Data

\section{POINTS}

Label Points $=575$

\section{ANNOTATIONS}

Subclass

(blank):

TOLERANCES

Fuzzy $\quad=0.795 \mathrm{~V}$

Dangle $=0.000 \mathrm{~V}$
Annotations

0
Text Attribute Data

0 bytes
SECONDARY FEATURES

$\begin{array}{llr}\text { Tics } & =632 \\ \text { Links } & =0\end{array}$

COVERAGE BOUNDARY

$\begin{array}{llll}X \min & =590070.062 & Y \min & =3873319.000 \\ X \max & =715785.312 & Y \max & =3984217.500\end{array}$

\section{STATUS}

The coverage has not been Edited since the last BUILD or CLEAN.

NO COORDINATE SYSTEM DEFINED 
Description of SINGLE precision coverage kingmanf

ARCS

Arcs $=613$

Segments $=3715$

28 bytes of Arc Attribute Data

NODES

Nodes $=704$

0 bytes of Node Attribute Data

TOLERANCES

$\begin{array}{ll}\text { Fuzzy } & =10.648 \mathrm{~V} \\ \text { Dangle } & =0.000 \mathrm{~V}\end{array}$

COVERAGE BOUNDARY

$\mathrm{Xmin}=\mathbf{5 8 9 1 8 0 . 3 7 5}$

$\mathrm{Xmax}=707274.125$
POLYGONS

Polygons $=0$

There is NO Polygon Topology.

0 bytes of Polygon Attribute Data

\section{POINTS}

Label Points $=0$

SECONDARY FEATURES

Tics $\quad=632$

Links $\quad=0$

\section{STATUS}

The coverage has not been Edited since the last BUILD or CLEAN.

NO COORDINATE SYSTEM DEFINED 
ARCS

Arcs $\quad=2518$

Segments $=58135$

0 bytes of Arc Attribute Data

NODES

Nodes $=2065$

0 bytes of Node Attribute Data

\section{POLYGONS}

Polygons $=584$

Polygon Topology is present.

24 bytes of Polygon Attribute Data

POINTS

Label Points $=583$

\section{ANNOTATIONS}

Subclass

(blank):

TOLERANCES

Fuzzy $\quad=1.000 \mathrm{~V}$

Dangle $=0.030 \mathrm{~V}$
Annotations

0

Text Attribute Data

0 bytes
SECONDARY FEATURES

Tics $=632$

Links $=0$

COVERAGE BOUNDARY

$X \min =410607.531$

$\mathrm{Ymin}=4094568.000$

$X \max =481918.906$

$Y \max =4160245.500$

\section{STATUS}

The coverage has not been Edited since the last BUILD or CLEAN.

NO COORDINATE SYSTEM DEFINED 


\section{Description of SINGLE precision coverage mariposaf}

ARCS

Arcs $=673$

Segments $=3021$

28 bytes of Arc Attribute Data

NODES

Nodes $=911$

0 bytes of Node Attribute Data

TOLERANCES

Fuzzy $\quad=0.837 \mathrm{~V}$

Dangle $=0.000 \mathrm{~V}$

\section{POLYGONS}

Polygons $=0$

There is NO Polygon Topology.

0 bytes of Polygon Attribute Data

POINTS

Label Points $=0$

SECONDARY FEATURES

Tics $=631$

Links $=0$

COVERAGE BOUNDARY
$X \min =393650.250$
$Y \min =4094250.000$
$X \max =482550.625$
$Y \max =4196279.000$

\section{STATUS}

The coverage has not been Edited since the last BUILD or CLEAN.

NO COORDINATE SYSTEM DEFINED 
ARCS

$$
\begin{array}{lcc}
\text { Arcs } & = & 5499 \\
\text { Segments } & = & 152700 \\
\text { 0 bytes of Arc Attribute Data }
\end{array}
$$

NODES

Nodes $\quad=\quad 3847$
0 bytes of Node Attribute Data

\section{POLYGONS}

Polygons $=2342$

Polygon Topology is present.

20 bytes of Polygon Attribute Data

\section{POINTS}

Label Points $=2341$

\section{ANNOTATIONS}

Subclass
(blank):

TOLERANCES
Fuzzy $\quad=0.900 \mathrm{~V}$
Dangle $=0.000 \mathrm{~V}$

Annotations

0
Text Attribute Data

0 bytes

SECONDARY FEATURES

Tics

$=632$

Links

$=0$

\section{COVERAGE BOUNDARY}

$\begin{array}{ll}X \min & =408732.094 \\ X \max & =591207.250\end{array}$

Ymin

$=3872779.500$

$Y \max$

$=3984176.750$

\section{STATUS}

The coverage has not been Edited since the last BUILD or CLEAN.

NO COORDINATE SYSTEM DEFINED 
Description of SINGLE precision coverage tronaf

ARCS

Arcs $=2125$

Segments $=11964$

28 bytes of Arc Attribute Data

NODES

Nodes $=2903$

0 bytes of Node Attribute Data

TOLERANCES

$\begin{array}{ll}\text { Fuzzy } & =50.867 \mathrm{~V} \\ \text { Dangle } & =0.000 \mathrm{~V}\end{array}$
POLYGONS

Polygons $=0$

There is NO Polygon Topology.

0 bytes of Polygon Attribute Data

\section{POINTS}

Label Points $=0$

SECONDARY FEATURES

Tics $\quad=632$

Links $=0$

COVERAGE BOUNDARY

$\begin{array}{llll}X \min & =408880.062 & Y \min & =3872026.000 \\ X \max & =591840.125 & Y \max & =3985403.500\end{array}$

\section{STATUS}

The coverage has not been Edited since the last BUILD or CLEAN.

NO COORDINATE SYSTEM DEFINED 